\title{
Factors Determining Profitability of the Insurance Industry of Bangladesh
}

\author{
G M Wali Ullah \\ School of Business, Independent University, Bangladesh \\ E-mail:wali@iub.edu.bd \\ Mohammed Nasrath Faisal \\ College of Management, University of Massachusetts Boston, United States \\ E-mail: nasrathfaisa1007@gmail.com \\ Sadaqa Tuz Zuhra \\ School of Business \& Economics, North South University, Bangladesh \\ E-mail: sadaqatuzzuhra@yahoo.com
}

Received: Aug. 20, 2016

Accepted: Sept. 12, 2016

Published: Oct. 17, 2016

doi:10.5296/ifb.v3i2.9954

URL: http://dx.doi.org/10.5296/ifb.v3i2.9954

\begin{abstract}
Insurance is a form of risk management, used to hedge against the risk of a contingent loss. It involves the transfer of the risk of potential loss from one entity to another, in exchange for a risk premium. Insurance sector plays an important role in service based economy of both developed and developing markets. The purpose of this research is to analyze the determinants that serve as significant predictors of non-life insurance firms' profitability in Bangladesh. It analyzes panel data of eight different insurance companies - selected using convenience sampling method from the years 2004-2014 to assess whether any significant relationship exists between Profitability (ROA), and certain independent variablesUnderwriting Risk, Expense Ratio, Solvency Margin, Premium Growth, Asset Growth, and Company Size using an Ordinary least squares (OLS) regression model. This paper found significant inverse relationship between Underwriting Risk, and Size, with Profitability (ROA). There is also a significant positive relationship between Expense Ratio, Solvency Margin, and Growth, with the Profitability (ROA). This study will help financial managers to understand which internal factors to focus on, in order to achieve greater profitability, thus
\end{abstract}


maximizing the market value of the respective insurance company.

Keywords: Profitability, Insurance industry, Bangladesh, Dhaka Stock Exchange (DSE) 


\section{Introduction}

Insurance is a form of risk management, used to hedge against the risk of a contingent loss. It involves the transfer of the risk of potential loss from one entity to another, in exchange for a risk premium. Therefore, the insurance sector fosters financial stability by enabling economic agents to undertake various transactions with the facility of transfer and dispersion of risks. The role of insurance as a financial intermediary is particularly important in countries like Bangladesh with low levels of financial penetration. Insurance companies play a large role in the service-based economy. The financial guarantee services that insurance companies provide, are now being integrated into the wider financial industry. Non-life insurance companies (both private and public) provide fire, marine, accident, causality and many other forms of insurance. In order to track their financial performance, one crucial measure monitored is profitability of the institution. Profitability is one of the most important objectives of financial management, because one of the goals of financial management is to maximize shareholders' wealth, and profitability is a very important determinant of performance (ECB, 2009; Ngoyen, 2006).

The insurance business started almost a century ago in Bangladesh, during the British regime in India. Between 1947-1971, the number of insurance companies in Bangladesh began to grow. There existed a total of 49 general insurance and life insurance companies during this period. After the liberation was in 1972, The People's Republic Government of Bangladesh nationalized the insurance industry, along with the banks, by Presidential Order No. 95. By virtue of this order, all insurance companies in Bangladesh operate their business under this nationalization order. The formation of the first five insurance companies in the public sector of Bangladesh after 1972 were-JatiyaBima Corporation, TistaBima Corporation, KarnafuliBima Corporation, RupsaJibanBima Corporation, and SurmaJibanBima Corporation. The Government permitted the insurance business in the private sector from 1984, after which the number of insurance companies swiftly grew in the private sector. There exists a total of 47 general insurance companies in Bangladesh, of which 37 are listed in the Dhaka Stock Exchange.

Generally, a firm's performance can be estimated by measuring its profitability, and insurer's performance is related to such potential determinants as underwriting risk, expense ratio, solvency margin, premium growth, assets growth and the size of the company. During the period of 2005-2014, the annual reports of non-life insurance firms in Bangladesh show large fluctuations in profits. This variation of profits among insurance companies suggests that firm-specific factors play crucial role in influencing profitability. The Bangladeshi insurance industry is a highly competitive industry. In recent years, the key factors affecting its performance included fierce competition in the non-life segment, rising market share of private insurance companies, and the increasing amount of risk being retained by insurers. It is therefore essential to identify what these factors are, how they can help insurance companies take actions that will increase their profitability, and how investors can forecast the profitability of insurance companies in Bangladesh.

This paper analyzes and identifies the determinants of profitability for the insurance sector of 
Bangladesh. There are 37 listed non-life insurance companies in Bangladesh, of which 8 were selected as samples, using convenience sampling method.

\section{Literature Review}

The insurance companies of Bangladesh perform a wide range of activities such as service designing, preparing contract and policy, marketing and selling, underwriting, rating, reinsurance and other services and claim settlement. The two governments owned insurance companies i.e., the ShadharanBima Corporation and JibanBima Corporation get all the government insurance business by virtue of the Insurance Act of Bangladesh. According to the rule, all insurance in the government sector is done through these two nationalized insurance companies, so they enjoy a monopoly. None of the private insurance companies are allowed to offer insurance services to government organizations. Furthermore, these two corporations are also allowed to underwrite private businesses, and people feel confident about their reliability. So they have not yet felt any strong need to practice marketing properly, and usually they have reported middling profits over the years.

There are many proxies to measure profitability, some of which are return on invested capital (ROIC), return on equity (ROE) and return on assets (ROA) (Nguyen, 2006). Profitability is affected by factors including the scale of policy holder's dividend, capital gain or losses and federal/state taxes for insurer (Wright 1992).

Koller (2011) in his investigation identified that insurance companies are playing the role of transferring risk channeling funds from one unit to the other (financial intermediation) such as general insurance companies and life insurance companies respectively. This implies that insurance companies are helping the economy of a country one way by transferring and sharing of risk which can create confidence over the occurrences of uncertain event and in another way insurance companies like other financial institutions plays the role of financial intermediation so as to channel financial resources from one to the other.

A factor determining financial performance of the insurance companies is the underwriting risk, which reflects the adequacy, or otherwise, of insurers' underwriting performance. Sound underwriting guidelines are pivotal to an insurer's financial performance. It depends on the risk appetite of the insurers. It is usually measured as the ratio of benefits incurred to net premium (Adams \& Buckle, 2000).

Investment performance discloses the effectiveness and efficiency of investment decisions. As such, investment performance becomes critical to the financial solidity of an insurer. Kim et al. (1995) and Kramer (1996) find that investment performance is negatively correlated to insolvency rate. Another study by Pervan \& PavićKramarić investigated the determinants of the Croatian non-life insurance companies' profitability during the period from 2003 to 2009. The results of the study indicate that ownership, expense ratio, and inflation have a negative and significant influence on profitability. However, past profitability has a positive and significant impact on Croatian non-life insurance companies' profitability (Pervan et al., 2010).

Solvency has also been used in researches as an indicator of the financial performance of 
insurance companies (Baourakis et al., 2002; Boyd et al., 2007) and how it affects the profitability of agricultural cooperatives. Hailu et al. (2005) estimated the influence of solvency in achieving cost minimization on a sample of Canadian agricultural cooperative. Their study showed that firm and industry characteristics must be accounted for in determining whether increased solvency generates statistically significant agency costs, which could come in the form of means for managers to make expenditures which increase their personal benefits and ignore owner preferences. Based on their analysis, only one of the cooperatives in their sample suffered from increased agency costs due to increased solvency. Schumacher \& Boland (2004), Boland, Golden, \& Tsoodle (2008), and Dorsey \& Boland (2009) have found that solvency is a significant variable in explaining the financial performance of firms in the four segments of the food economy (e.g., processing, wholesale grocery, retail supermarket, and restaurant). Thus, solvency is a logical variable to use when explaining profitability.

Empirical results show that rapid growth of premium volume is one of the causal factors in insurers' insolvency (Kim et al., 1995). Being too obsessed with growth can lead to self-destruction as other important objectives might be neglected. This is especially true during an economic downturn, such as the Asian Financial Crisis. Insurance companies having more and more assets over the years have also better chance of being profitable for the reason that they do have internal capacity though it depends on their ability to exploit external opportunities. Empirical evidence by Ahmed et al (2011) in Pakistan, Li (2007) in UK and Al-Shami (2008) in UAE of their investigation found a positive and statistically significant relationship between growth and profitability of insurance companies.

In most literatures, the effect of size on banks profitability is represented by total asset. Flamini et al. (2009) indicated that size is used to capture the fact that larger firms are better placed than smaller firms in harnessing economies of scale in transactions and enjoy a higher level of profits. One of the most important questions underlying bank policy is which size optimizes bank profitability. According to Athanasoglou et al. (2005) the effect of a growing size of a bank on profitability has been proved to be positive to a certain extent. Consequently, a positive relationship is expected between size and profitability by many insurance area researchers. As regulators are less likely to liquidate large insurers, it is expected that small insurers are more vulnerable to insolvency (BarNiv \& Hershbarger, 1990; Cummins, Harrington, \& Klein, 1995). However, for firms that become extremely large, the effect of size could be negative due to bureaucratic and other reasons Li (2007). Hence, the size-profitability relationship may be expected to be non-linear. Therefore most studies use the real assets in logarithm and their square in order to capture the possible non-linear relationship. Athanasoglou et al. (2005) and Li found positive relationship between size and profitability.

\section{Methodology and Data Analysis}

This is a formal study as clearly identified by the title. It is not a case study, but a generalized study/statistical report of the insurance industry of Bangladesh. Our sample size was only eight listed insurance companies from the Dhaka Stock Exchange (DSE)-selected through 


\section{MlMacrothink}

International Finance and Banking

ISSN 2374-2089

2016, Vol. 3, No. 2

random sampling. Ten years (2005-2014) of secondary data were used for the research, collected and calculated from their annual reports

\subsection{Regression Model}

Through the literature review, various relevant independent variables were identified that might have impact on the profitability of the insurance sector of Bangladesh. Based on that, the following Ordinary Least Squared (OLS) regression model was developed:

$$
\begin{gathered}
\text { ROA }=\alpha+\beta_{1} \text { Underwriting Risk }+\beta_{2} \text { Expense Ratio }+\beta_{3} \text { Solvency Margin }+\beta_{4} \text { Premium } \\
\text { Growth }+\beta_{5} \text { Assets Growth }+\beta_{6} \text { Size }+ \text { Error term }
\end{gathered}
$$

Where,

Dependent Variable $=$ Profitability $(\mathrm{ROA})$

Independent Variables $=$ Underwriting Risk, Expense Ratio, Solvency Margin, Premium Growth, Growth, and Size.

$\alpha=$ Constant

$\beta_{1}, \beta_{2}, \beta_{3}, \beta_{4}, \beta_{5}, \beta_{6}=$ Coefficients

\subsection{Data Analysis}

\subsubsection{Descriptive Analysis}

From our sample of eight general insurance companies, we have a total of 80 observations. We derived the following descriptive statistics output for the available information

Table 1. Descriptive statistics

\begin{tabular}{|l|l|l|l|l|l|l|l|}
\hline & ROA & UNDERWRITI & EXPENSE & RA-SOLVENCY & $\begin{array}{l}\text { PREMIUM- } \\
\text { GROWTH }\end{array}$ & GROWTH & SIZE \\
\hline Mean & 0.066963 & 0.092714 & 0.169369 & 5.043473 & 0.121958 & 0.162674 & 20.94288 \\
\hline Median & 0.060850 & 0.090750 & 0.174450 & 4.867800 & 0.112350 & 0.081500 & 20.91280 \\
\hline Maximum & 0.406000 & 0.504600 & 0.846500 & 8.088300 & 1.174100 & 1.449600 & 22.61020 \\
\hline Minimum & -0.168500 & -0.030800 & -0.442800 & 2.073500 & -0.365000 & -0.20850 & 19.39240 \\
\hline Std. Dev & 0.067781 & 0.062866 & 0.155744 & 1.512956 & 0.168051 & 0.256942 & 0.857354 \\
\hline
\end{tabular}

\subsubsection{Regression Analysis}

Annual panel data collected for 10 consecutive years, from 2005-2014, for eight different general insurance companies; a total of 80 observations were ran through the Ordinary Least Squared (OLS) regression model. 
Table 2. Regression output

Dependent Variable $=$ ROA (Profitability)

\begin{tabular}{|l|l|l|}
\hline Variable & Coefficient & Probability \\
\hline Intercept & 0.401006 & $(0.0206)^{*}$ \\
\hline Underwriting Risk & -0.356437 & $(0.0035)^{*}$ \\
\hline Expense Ratio & 0.099090 & $(0.0399)^{*}$ \\
\hline Solvency Margin & 0.016302 & $(0.0026)^{*}$ \\
\hline Premium Growth & 0.053081 & $(0.1886)$ \\
\hline Growth & 0.073970 & $(0.0049)^{*}$ \\
\cline { 1 - 2 } Size & -0.019983 & $(0.0235)^{*}$ \\
\cline { 1 - 2 } R-squared & 0.365480 & \multirow{2}{*}{} \\
\cline { 1 - 2 } Adjusted R-squared & 0.313328 & \multirow{2}{|l|}{} \\
\cline { 1 - 2 } Prob (F-Statistic) & $(0.000007)^{*}$ & \multicolumn{1}{|l|}{} \\
\cline { 1 - 2 } & &
\end{tabular}

Note. *denotes individual significance of the independent variable at $10 \%$ significance level.

As the regression output show, most of the independent variables of the model are individually significant relationship with profitability (ROA) of the insurance companies. Size and underwriting risk have negative coefficients, implying the inverse relationship present with profitability. Surprisingly, expense ratio had a positive coefficient, implying an increase in profitability as expense ratio goes up.

R-Squared signifies the level up to which the variations in the dependent variable (ROA), can be explained by our independent variables (Underwriting Risk, Expense Ratio, Solvency Margin, Premium Growth, Growth, and Size). The value of our R-squared $=0.365480$, which means that $36.5480 \%$ of the variations in Profitability (ROA) can be explained by the independent variables in our regression model, while other factors and variables that are not included in our model, is responsible for remaining $63.4520 \%$. This adds up to future research prospect in this area, as finding other relevant variables might explain the remaining variances of the profitability of insurance companies.

Probability of F-Statistic in this model is 0.000007 , which is much less than our significance level, meaning that our multiple regression model is a "good fit" in explaining the profitability of insurance companies of Bangladesh.

\section{Concluding Remarks}

Throughout the study, the objective was to determine which factors were responsible for affecting the ROA of general insurance firms in Bangladesh. In order to conduct this formal research to achieve our objectives, this study gathered secondary data of 10 years (2005-2014) of these publicly listed general insurance firms, traded in the Dhaka Stock Exchange (DSE). The findings concluded that all independent variables, except premium growth, have significant impact on ROA. The underwriting risk and size have a negative relationship with ROA, of which underwriting risk has a moderately significant impact, whereas size has a 
weak impact. On the other hand, expense ratio, solvency margin, and growth have a positive relationship with ROA. Although the relationship is weak, it is recommended that financial managers, and investors, should focus on these determinants when making decisions to maximize market value of the firm, or when making investment decisions.

This study was intended to determine which factors significantly affect the profitability of non-life insurance firms in Bangladesh, from eight general insurance companies listed in the Dhaka Stock Exchange (DSE). The insurance sector is a vast area so, it is difficult to come to a conclusion from only analyzing eight companies' data. Further research may be directed towards including more relevant variables as well as a bigger sample to address the issue of how profitability of insurance companies get affected, and how it can be improved upon.

\section{References}

Adams, M., \& Buckle, M. (2000). The Determinants of Operational Performance in Bermuda Insurance Market. Applied Financial Economics, 13, 133-143. http://dx.doi.org/10.1080/09603100210105030

Ahmed, N., Ahmed, Z., \& Ahmad, U. (2011). Determinants of Performance: A Case of Life Insurance Sector of Pakistan. International Research Journal of Finance and Economics. Eurojournals Publishing, Inc. [Online] Available: http://www.eurojournals.com/Finance.htm

Athanasoglous, P. et al. (2005). Bank-Specific, Industry- Specific and Macroeconomic Determinants of Bank Profitability. Bank of Greece Working Paper, No. 25.

Baourakis, G., Doumpos, M., Kalogeras, N., \& Zopounidis, C. (2002). Multicriteria Analysis and Assessment of Financial Viability of Agribusinesses: The Case of Marketing Cooperatives and Juice-Producing Companies. Agribusiness, 18(4), 543-558. http://dx.doi.org/10.1002/agr.10031

BarNiv, R., \& Hershbarger, R. A. (1990). Classifying Financial Distress in the Life Insurance Industry. Journal of Risk and Insurance, 57, 110-136. http://dx.doi.org/10.2307/252927

Boland, M. A., Golden, B., \& Tsoodle, L. (2008). Agency Problems in the Food Processing Industry. Journal of Agricultural and Applied Economics, 40(2), 623-634. http://dx.doi.org/10.1017/S1074070800023890

Browne, M. J., \& Hoyt, R. E. (1995). Economic and Market Predictors of Insolvencies in the Property-Liability Insurance Industry. Journal of Risk and Insurance, 62, 309-327. http://dx.doi.org/10.2307/253794

Cummins, J. D., Harrington, S. E., \& Klein, R. (1995). Insolvency Experience, Risk-Based Capital and Prompt Corrective Action in Property-Liability Insurance. Journal of Banking and Finance, 19, 511-527. http://dx.doi.org/10.1016/0378-4266(94)00136-Q

Dorsey, S., \& Boland, M. A. (2009). Vertical Integration in the U.S. Food Economy. Journal of Agricultural and Applied Economics. Cambridge: Cambridge University Press.

European Central Bank. (2009). Financial Stability Review 2008-2009. 


\section{Macrothink}

International Finance and Banking ISSN 2374-2089 2016, Vol. 3, No. 2

Featherstone, A., \& Al-Kheraiji, A. (1995). Debt and Input Misallocation of Agricultural Supply and Marketing Cooperatives. Applied Economics, 27, 871-878. http://dx.doi.org/10.1080/00036849500000040

Flamini, V., McDOnald, C., \& Schumacher, L. (2009). The Determinants of Commercial Bank Profitability in Sub-Saharan Africa. IMF Working Papers, No 09/15, pp. 1-30.

Hailu, G., Jeffrey, S., Goddard, E., \& Ng, D. W. (2005). Regulatory Environment, Cooperative Structure, and Agency Costs for Cooperative Agribusiness Firms in Canada: Comparative Case Studies. Journal of Food Distribution Research, 36(2), 39-49.

Kashish, K. (1998). Actors affecting the profitability of insurance companies in Jordan. Working Paper, Alyarmouk University, Jordan.

Khan, M. S. U., \& Uddin, M. N. (n. d.). Insurance Industry in Bangladesh: Opportunities and Challenges. Thoughts on Economics, 23(4).

Kim, Y. D., Anderson, D. R., Amburgey, T. L., \& Hickman, J. C. (1995). The Use of Event History Analysis to Examine Insurer Insolvencies. Journal of Risk and Insurance, 62, 94-110. http://dx.doi.org/10.2307/253694

Kramer, B. (1996). An Ordered Logit Model for the Evaluation of Dutch Non-Life Insurance Companies. De Economist, 144, 79-91. http://dx.doi.org/10.1007/BF01680262

Li, Y. Q. (2007). Determinants of Banks' Profitability and Its Implication on Risk Management Practices: Panel Evidence from the UK. University of Nottingham.

Nguyen, K. M. (2006). Financial Management and Profitability of Small and Medium Enterprises. Southern Cross University Thesis Submitted to the Graduate College of Management in partial fulfillment of requirements for the degree of Doctor of business Administration.

Pervan, M., \& PavićKramarić, T. (2010). Determinants of insurance companies' profitability in Croatia. Bus. Rev. Camb. 16, 231-238.

Rejda, G. E. (2001). Principles of Risk Management and Insurance (7th ed.). Reading, MA: Addison Wesley.

Schumacher, S., \& Boland, M. A. (2005). Persistence in Profitability in Food and Agribusiness Firms. American Journal of Agricultural Economics, 87(1), 103-115. http://dx.doi.org/10.1111/j.0002-9092.2005.00705.x

Wright, K. M. (1992). The Life Insurance industry in the United States an analysis of economic and regulatory issues. Country Economics Department the World Bank policy research working paper (wps 857). 


\section{Copyright Disclaimer}

Copyright for this article is retained by the author(s), with first publication rights granted to the journal.

This is an open-access article distributed under the terms and conditions of the Creative Commons Attribution license (http://creativecommons.org/licenses/by/3.0/). 